\title{
KONSEP SUNNAH DALAM PERSPEKTIF AHMAD AMIN
}

\author{
Atho'illah Umar \\ Universitas Islam Negeri Sunan Ampel Surabaya \\ a.umar@uinsby.ac.id
}

\begin{abstract}
The earliest discourse on hadith revolves around the attempts to record in a written material, which in several accounts of Prophetic traditions are banned to write. This issue further becomes the center of the problem on the authority and authenticity of the hadiths where many of scholars have paid attention on its discussion. This article was an attempt to reconceptualize a theory of hadith criticism initiated by Ahmad Amin. Through his book Fajr al-Islam, Amin, among others, questioned the originality of the hadith after the death of the Prophet. He recounted the concept of sunnab by questioning its authenticity after the death of the Prophet. This article also presents a theoretical criticism to some extend gives some responds to those who contend the concept of 'adalat al-sahäbah, a concept whose existence has been agreed upon as a measure of hadith measurement by scholars of muhaddithin.
\end{abstract}

Keywords: Ahmad Amin, Authenticity, 'adalat al-sahăabah.

Abstrak: Diskursus awal tentang hadis berkisar tentang usaha untuk merekamnya dalam bentuk material tertulis, yang dalam beberapa riwayat Nabi Muhammad melarang untuk menuliskannya. Isu inilah yang kemudian menjadi cikal bakal problematika otoritas dan otentisitas hadis yang hangat diperbincangkan oleh para sarjana. Artikel ini hendak mendiskusikan kembali salah satu tokoh kritikus hadis, Ahmmad Amin. Melalui bukunya Fajr al-Islam, Amin, di antaranya, mempertanyakan orisinalitas hadis pasca wafatnya Nabi. Dia mengurai ulang tentang konsepsi sunnah dengan mempertanyakan tentang otentitasnya pasca wafatnya Nabi. Artikel ini juga akan mengetengahkan kritikan beberapa ulama atas pemikirannya yang menentang konsep 'adalat al-sabāabah (keadilan sahabat), sebuah konsep yang keberadaannya telah disepakati sebagai tolak ukur penilaian hadis oleh para ulama hadis (muhaddithin).

Kata kunci: Ahmad Amin, Otentitas, 'adalat al-sahạabah. 


\section{Pendahuluan}

Hadis merupakan sumber otoritatif dalam merumuskan ajaran Islam setelah Alquran. Di dalamnya memuat pernyataan, pengamalan, dan pengakuan yang disandarkan pada Nabi Muhammad, di mana segala tindak-tanduk Nabi bersumber dari Alquran itu sendiri. Dengan kata lain, posisi hadis tidak kurang sebagai salah satu bentuk manifestasi Alquran, sehingga dapat dikatakan bahwa percaya kepada hadis atau sunnah adalah bagian dari iman di dalam agama dan menerima sunnah merupakan bagian dari menerima agama, seperti terungkap dalam sebuah äthär populer:

$$
\text { ان هذا العلم دين فانظروا عمن تأخذون دينكم }
$$

"sesungguhnya ilmu hadis ini adalah agama, maka periksalah dari siapa kalian mengambil agama kalian".

$\bar{A}$ thar tersebut setidaknya menjelaskan dua poin penting; pertama, penilaian yang sangat tinggi terhadap sunah, di mana ia diterapkan sebagai agama, sehingga menerima dan membenarkannya merupakan keharusan dalam beriman. Kedua, perlunya metode yang benar dan standar dalam melakukan penilaian dan penelitian terhadap kebenaran sunah.

Berdasar pada perlunya suatu metode yang standar dalam penilaian dan penelitian sunah, menunjukkan betapa besar keseriusan umat Islam dalam melestarikan sunah sebagai sumber pokok ajaran agama. Hal ini dapat dilihat dari keseriusan para sahabat dalam mendapatkan dan menjaga keotentikan hadis. Para sahabat terobsesi untuk mengikuti segala apa yang mereka lihat dan dengar dari Nabi Muhammad. Mereka bertekad untuk mendata sunah Rasulullah. Karena itu, ada di antara mereka yang mengadakan giliran mengikuti majelis-majelis ilmu yang dilaksanakan Nabi. Mereka yang tidak bisa menghadiri majlis Nabi Muhammad dapat memperoleh keteranganketerangan melalui sahabat lain yang menyertai Nabi. Demikian itu mereka lakukan secara bergantian dan terus menerus.

Selanjutnya tradisi yang dilakukan para sahabat, kemudian dilanjutkan oleh para tabiin (generasi setelah sahabat), berlanjut kemudian generasi berikutnya, dan akhirnya dapat dikatakan bahwa upaya menjaga kemurnian sunah tidak pernah berhenti. Dalam perjalanan, hadis mengalami perkembangan sedemikian rupa, dari kodifikasi yang lebih rumit dari pada Alquran, hingga beredarnya pernyataan yang disandarkan pada Nabi namun cukup problematik 
dari segi jalur transmisi atau isi, belakangan hadis bermasalah semacam ini disebut palsu.

Sifat hadis yang lebih kompleks dari Alquran, dengan demikian terbuka untuk dikaji terus menerus, baik untuk mempertanyakan klaim-klaim ulama yang seolah sudah final, maupun memperbarui paradigma-paradigma kajian hadis. Dalam riset ini, penulis akan mengangkat pandangan Ahmad Amin seputar otentisitas Sunnah dan pendapatnya tentang kritik sanad dan matan yang ia kemukakan dalam 3 karya fenomenalnya, Fajr al-Isläm, Ḍuḅa al-Isläm dan Yawm al-Isläm.

\section{Biografi Ahmad Amīn}

Aḥmad Amin dilahirkan di Kairo para tanggal 1 Oktober 1886, empat tahun setelah penjajahan Inggris, dengan nama lengkap Ahmad Amin b. Ibrāhìm al-Tabbākh. Ia adalah seorang sastrawan, pemikir, sejarawan dan penulis. Masa-masa ini termasuk masa yang sangat genting bagi Mesir modern. Ia menyadari bahwa kelahirannya pada tanggal itu adalah pertanda bahwa ia akan ditakdirkan menjadi seorang guru, karena 1 Oktober adalah hari pertama tahun ajaran baru sekolah.

Ahmad Amin terlahir sebagai anak bungsu dari empat bersaudara dalam lingkungan keluarga terdidik dan disiplin. Dalam otobiografi yang yang ditulis beberapa tahun menjelang wafat (1950), Ahmad Amin mengatakan bahwa ia menimba ilmu pengetahuan di rumahnya sendiri kepada ayahnya. Sebagaimana ciri khas keluarga berpendidikan, rumah keluarga Ahmad Amin dipenuhi berbagai koleksi literatur dari berbagai genre keilmuan seperti fikih, tafsir, hadis, balagah, sejarah, sastra, nahwu, saraf. Dalam keseharian, waktu Ahmad Amin banyak dihabiskan untuk membaca kitab-kitab tersebut. $^{1}$

Setelah mendapatkan pendidikan di lingkungan keluarga, ia kemudian masuk ke pendidikan formal yaitu Ibtidaiyah "Walidah Abbas Pasha". Kemudian ia melanjutkan ke perguruan tinggi al-Azhar, Kairo, Fakultas Syariah jurusan al-qadà al-shar $\bar{i}$ (Peradilan Agama). Ayahnya mengarahkannya ke mazhab Hanafi karena mazhab itulah yang biasa digunakan dalam peradilan agama.

Pada tahun 1911 ia lulus dengan mendapatkan ijazah kehakiman. Setelah lulus, ia belajar bahasa Perancis dan Inggris dengan sangat

${ }^{1}$ Aḥmad Amin, Hayâtī (Kairo: Hindawi li al-Ta 'Tim wa al-Thaqāăah, 2011), 19. 
serius: "Aku tempuh segala cara untuk mewujudkan cita-citaku menguasai bahasa Inggris," dan ia pun berhasil mendapatkannya. Lalu ia diminta untuk mengajar di almamaternya itu selama dua tahun. Kemudian pada tahun 1913 ia magang di kehakiman selama tiga bulan, setelah itu kembali lagi ke al-Azhar untuk mengajar. ${ }^{2}$

Pada tahun 1926, temannya, Ṭahā Ḥusayn mempromosikannya ke Universitas Kairo untuk menjadi salah satu staf pengajar di fakultas Adab. Ia pun manjadi dosen tetap di sana dan mengajar mata kuliah "al-naqd al-adabi" dan mendapat jabatan Profesor Muda tanpa doktor, hingga pada tahun 1939 ia diangkat menjadi Dekan di fakultas tersebut. Selain memangku jabatan, Ahmad Amin termasuk penulis yang produktif, bahkan ia dinobatkan sebagai ketua Komite Pengarang, Penerjemah dan Penerbitan selama 30 tahun. Jabatan inilah yang mendudukannya menjadi pengarang dan penulis yang terkemuka. Sebelum menjadi dekan ia berhasil menyelesaikan proyek bukunya Fajr al-Isläm dan duhāa al-Isläm.

Baru dua tahun menjabat dekan, ia mengundurkan diri sebagai sikap protes terhadap kebijakan Menteri Pendidikan, M. Husayn Haykal yang memutuskan untuk memindahkan beberapa staf pengajar Fakultas Adab ke Iskandariyah tanpa sepengetahuan Ahmad Amin selaku dekan. Ketika ia mengundurkan diri dan memutuskan untuk menjadi dosen biasa ia mengatakan "Saya lebih kecil dari guru dan lebih besar dari dekan." Ia merasa lega melepas jabatan dekan karena selama menjadi dekan, ia tidak bisa lagi produktif, masa-masa itu ia sebut sebagai masa paceklik ilmiah atau kemandulan berfikir.

Ketika menjadi dekan, ia sempat melakukan kunjungan di beberapa negara Arab dan Eropa, bahkan ia pernah mewakili Mesir dalam sebuah Konferensi Palestina yang diadakan di London. Keikutsertaan ini adalah berkat rekomendasi dari temannya Ahmad Luṭ̂̄i Paṣa al-Sayyid yang saat itu menjabat Menlu Mesir.

Bersama teman-temannya ia mendirikan Lajnah al-Ta'lif wa alTarjamah wa al-Nashr pada tahun 1914 dan menjadi direktur seumur hidup. Ia juga pernah terlibat dalam lahirnya jurnal Al-Risālah pada tahun 1936, lalu jurnal sastra mingguan Al-Thaqäfah (1939). Di beberapa halaman jurnal ini ia pernah memuat perbincangannya dengan beberapa pemikir masa itu seperti Zaki Naj̄ib Maḥmūd yang pernah mengangkat isu tentang turäth Arab dan kebangkitan Barat.

2 Ibid., 121. 
Ia pernah menjadi direktur kantor kebudayaan dalam kementrian pendidikan tahun 1945. Pada tahun 1946 ia mendirikan Al-Jämi'ah alShabiyah yang bertujuan untuk membumikan kebudayaan di masyarakat melalui ceramah-ceramah atau kelompok diskusi. Pada tahun itu juga ia mendirikan Ma'bad al-Makhtütat al-'Arabijah di bawah naungan Jami'at al-Duwal al-'Arabiyah. Ia pernah menjadi anggota korespondensi di al-Majma' al-Tlmi al-'Arabì Damaskus dan al-Majma' al-Ilmi al-Iraq $\bar{i}$ sejak tahun 1926, juga menjadi anggota Majma' alLughah al-'Arabijah sejak tahun 1940 dan menjadi anggota al-Majlis alAlà li Där al-Kutub pada tahun 1939.

Dunia politik menurut Amin tidak bisa dibedakan dengan "Patriotisme." Pengetahuannya tentang politik banyak ia dapat dari gurunya Atif Bik Barakat yang pernah membimbing Amin selama 18 tahun sebelum ia menjadi dosen. Patriotisme Amin sempat menarik perhatian Presiden Sa'ad Zaghloul terutama dari reportase yang ia tulis tentang keadaan Mesir pasca revolusi 1919. Meski demikian Ahmad Amin tidak suka terjun ke politik karena ia akui takut akan hukuman atau penjara. Dan politik menurutnya adalah penghalang bagi kebebasan berfikir.

Ahmad Amin termasuk pemikir produktif. Mayoritas karyanya adalah di bidang pemikiran, sastra, sejarah dan kebudayaan Islam. Karya-karyanya antara lain: Fajr al-Isläm, Ḍuḅa al-Isläm, Zubür al-Isläm,

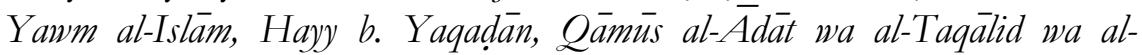
Ta'ayir al-Misniyah, Min zu'amà' al-islāh, Kitāb al-Akbläq, Hayatì, Fayd alKathir, Al-Sharq wa al-Gharb, Al-Naqd al-'Arabì, Härun al-Rashid, AlSa'lakah wa al-Fitnah fì al-Islam, Al-Mahdì wa al-Mahdawijah, Ilà Waladī, Qissat al-Falsafah al-Yünaniyah, Qissat al-Falsafah al-Hadithah, Qissat al-

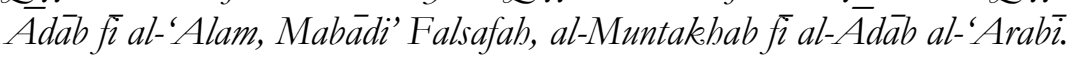

Ahmad Amin menghembuskan nafas terakhirnya pada tanggal 30 Mei 1954 M / 27 Ramadan 1373 H di usianya yang ke-68. ${ }^{3}$

\section{Makna Sunnah Perspektif Ahmad Amin}

Tidak jauh berbeda dengan ulama sebelumnya, Ahmad Amin mendefinisikan sunah sebagai "segala perkataan, perbuatan, dan

3 http://www.al-jazirah.com/2001/20010820/cu3.htm. Diakses pada 7 Januari, 2018;

http://www.marefa.org/index.php/\%D8\%A3\%D8\%AD $\%$ D $\% \% 85 \% \mathrm{D} 8 \%$ AF_\%D 8\%A3\%D9\%85\%D9\%8A\%D9\%86. Diakses pada 7 Januari 2018. 
ketetapan Nabi Muhammad". Kata "sunnah" berasal dari kata "sannā" yang berarti menggariskan, mengajarkan atau meninggalkan sebuah kebiasaan atau cara hidup. Dari sini, maka makna "sunnah" adalah cara atau kebiasaan yang baik. Dalam Alquran kata ini beberapa kali disebutkan: ${ }^{5}$

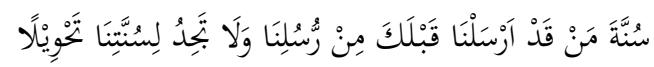

"Yang demikian itu) merupakan ketetapan bagi para rasul Kami yang Kami utus sebelum engkau, dan tidak akan engkau dapati perubahan atas ketetapan Kami. (QS. al-Isrä' [17]: 77).”’

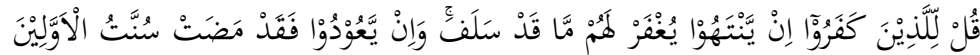

"Katakanlah kepada orang-orang yang kafir itu (Abu Sufyan dan kawan-kawannya), "Jika mereka berhenti (dari kekafirannya), niscaya Allah akan mengampuni dosa-dosa mereka yang telah lalu; dan jika mereka kembali lagi (memerangi Nabi) sungguh, berlaku (kepada mereka) sunah (Allah terhadap) orang-orang dahulu (dibinasakan). (QS. al-Anfall [8]: 38).”

Dari ayat ini kemudian kaum Muslimin menyadur (iqtibās) kata sunnah dan digunakan untuk menyebut sunah Nabi dan sahabatnya. ${ }^{8}$

${ }^{4}$ Aḥmad Amin, Fajr al-Islam (Beirut: Dār al-Kutub al-'Arabi, 1969), 208.

5 Ahmad Amin, Yawm al-Islam (Kairo: Maktabat al-Nahḍah al-Mișriyah, t.th.), 12.

6 Departemen Agama RI, Al-Hikmah: Al-Qur'an dan Terjemahnya (Bandung: Diponegoro, 2008), 290.

7 Ibid., 181.

${ }^{8}$ Amin, Yawm al-Isläm, 13. Kata 'sunnah' dan 'ḅadith' sebenarnya sudah ada sejak zaman Rasulullah dan istilah ini bukan hal baru dari umat Islam baik dari sahabat maupun tabiin setelah Rasulullah wafat. Ini dapat dibuktikan melalui beberapa hadis yang menyebutkan dua istilah tersebut dari Rasulullah sendiri. Berikut adalah buktibukti pernyataan Nabi mengenai sunnah dan hadith:

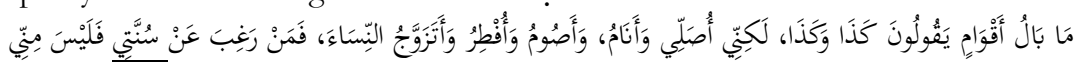

Lihat Ahmad b. Shu'ayb al-Nasāì', Al-Sunan al-Sughrā, ed. 'Abd al-Fattāh Abū Ghaddah, vol. 6 (Alepo: Maktab al-Maṭū'ah al-Islāmiyah, 1986), 60.

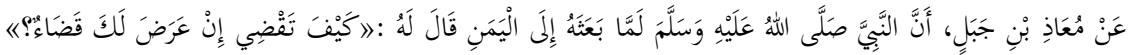

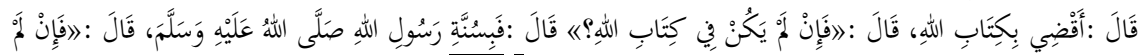

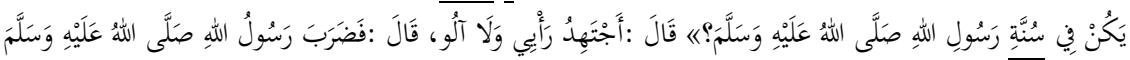

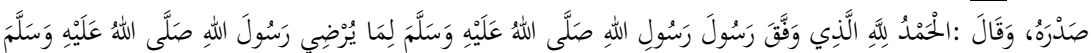
Lihat Sulaymān b. Aḥmad al-Ṭabrāni, Al-Mu'jam al-Kabir, ed. Hamdi b. 'Abd alMajid, vol. 20 (Kairo: Maktabat Ibn Taymiyah, 1994), 170. 
Dalam Fajr al-Islam, Amin membedakan antara sunnah dan hadis. Sunnah hanya disandarkan kepada Rasulullah sementara hadis disandarkan kepada Rasulullah dan sahabatnya. Tetapi dalam buku satunya, Yawm al-Islam, ia justru mengatakan bahwa hadis khusus untuk segala perkataan dan perbuatan yang disandarkan kepada Rasulullah meski dilakukan hanya sekali dan diriwayatkan oleh satu orang. Sedangkan sunnah adalah segala yang disandarkan kepada para sahabat dan tabiin. ${ }^{\text {? }}$

Tugas hadis terhadap Alquran menurut Amin adalah sebagai perinci kandungan ayat yang masih umum; mengkhususkan ayat yang masih mencakup persoalan global. Misalnya Alquran hanya memerintahkan salat secara umum, maka hadis bertugas untuk mentafsiil (merinci) mengenai kewajiban pelaksanaan salat tersebut tentang waktu dan aspek teknis pelaksanaannya. Contoh lain adalah mengenai ayat yang mengharamkan khamr (QS. al-Māidah [5]: 90) yang cukup global, hadis kemudian merinci terkait aspek definisi khamr, berapa kadar yang diharamkan dan sebagainya. Terkadang ayat turun untuk menjawab pertanyaan atau masalah yang sedang dihadapi umat ketika itu, meski tidak semua. Kedua tipe ayat ini masing-masing membutuhkan bantuan hadis untuk menjelaskan. ${ }^{10}$

Aḥmad Amin tidak berseberangan dalam hal kehujahan sunah. Menurutnya, sunah adalah salah satu sumber primer Islam dan menempati posisi kedua setelah Alquran. Amin tidak setuju dengan kelompok 'inkär al-sunnab' yang ia pandang 'berani membuang' sunah dengan menganggap bahwa mengamalkan Alquran sudah cukup dan tidak perlu lagi tambahan amalan dari sunah. Pandangan ini disalahkan oleh Amin karena sunah adalah penafsir bagi ayat-ayat Alquran yang masih mujmal, 'am, mutlaq, mushkil dan mubham. Secara historis, Rasulullah adalah 'problem solver' bagi semua persoalan umat.

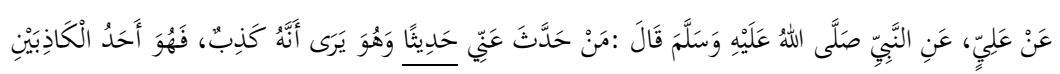
"barangsiapa yang meriwayatkan sebuah hadis (mawd du" dan menisbatkan kepadaku) sedangkan dia tahu bahwa itu adalah mawd $\bar{u}$, maka ia (perawi) adalah salah satu dari dua pendusta (yang satu lagi adalah pencipta hadis mawd $\bar{u}$. Teks-teks hadis marfuk ini menjadi bukti kuat bahwa istilah 'baditt' dan 'sunnab' sudah digunakan oleh Rasulullah kemudian diikuti oleh semua sahabatnya. Lihat Muhammad b. Yazid b. Mājah al-Qazwinī, Al-Sunan, vol. 1 (Kairo: Dār Ihyā' al-Kutub al-‘Arabiyah, t.th.), 14.

${ }^{9}$ Amin, Fajr al-Isläm, 208; Amin, Yawm al-Isläm, 12.

${ }^{10}$ Amin, Fajr al-Islam, 208. 
Dari sunah, dapat diketahui sejarah kehidupan sahabat, bagaimana mereka mengamalkan Alquran, bagaimana mereka meneladani Rasulullah, bagaimana mereka sukses membangun sebuah negara madani bersama Rasulullah. Singkatnya, hadis dapat membantu mengetahui sejarah umum Nabi dan sahabat. ${ }^{11}$ Lebih lanjut Ahmad Amin mengklasifikasikan hadis dalam tiga bentuk :

1. hadis-hadis akhlaq dan pendidikan. Kelompok hadis ini memuat hikmah, sopan santun, moral, nasihat sifat mulia seperi kejujuran, adil, ihsan, dan mencela sifat-sifat buruk seperti bohong, berbuat zalim, fasik, dan melakukan kerusakan (vandalisme).

2. hadis-hadis akidah dan menjadi penegas atas konsep tauhid, sifat-sifat Allah, kenabian dan risalah, hari pembangkitan dan pembalasan sebagaimana yang telah dimuat Alquran.

3. hadis-hadis abkam. hadis yang memuat hukum-hukum dalam Islam yang meliputi berbagai lini kehidupan. Khusus kelompok ini, ia mensyaratkan sebuah hadis abkeam harus berstatus sahih. ${ }^{12}$

\section{Kodifikasi Hadis}

Menurut Ahmad Amin, pada masa Rasulullah tidak ada upaya untuk mengkodifikasi hadis karena Rasulullah memberikan banyak konsentrasi untuk mengumpulkan Alquran dan melarang para sahabat menulis hadis. Langkah ini diambil sebagai upaya menghindari percampuran antara Alquran dengan hadis.

Amin mengakui bahwa ada sejumlah sahifah (kumpulan atau catatan hadis) milik beberapa sahabat pada masa Nabi. Akan tetapi itu tidak berarti bahwa hadis sudah terkodifikasi. ${ }^{13}$ Sebaliknya, proses tadwin terhadap hadis sama sekali belum direncanakan. Bahkan setelah Rasulullah wafat, periwayatan hadis masih menggunakan cara lisan dan hanya mengandalkan kekuatan hafalan para perawi. Beberapa sahabat ada yang tidak suka dengan banyaknya periwayatan hadis (sepeti Abū Bakr, 'Umar, dan 'Ali) karena mereka khawatir ada upaya

\footnotetext{
11 Amin, Yawm al-Islam, 12.

12 Ibid.

13 Dalam Yawm al-Islam, Amin justru lebih dekat dengan pendapat mayoritas ulama hadis. Ia mengatakan 'wa qad budi'a jam' al-hadith fị hayat al-rasul thumma kathura dhälike ba'dahu', sungguh hadis pada masa Rasulullah sudah mulai dikumpulkan/terkodifikasi-meski sedikit-dan pada masa-masa setelah beliau wafat, kodifikasi hadis sudah dilakukan secara massif. Ibid., 13.
} 
pemalsuan atau mengganggu konsentrasi mereka dalam gerakan kanonisasi Alquran. ${ }^{14}$

Meski demikian, permasalahan umat Islam semakin hari semakin kompleks dan bertambah. Dari sini banyak para sahabat menganggap kebutuhan akan hadis tidak bisa ditawar lagi. Kegiatan penulisan hadis mulai dilakukan umat Islam baik secara individual maupun kolektif demi melayani kebutuhan sumber syariat kedua setelah Alquran. Umat Islam kala itu membutuhkan mass storage selain otak manusia yang memberikan ruang lebih banyak untuk menyimpan hadis Nabi. Khalifah-khalifah pada awal Islam sebenarnya sudah sering berunding untuk mengkodifikasi sunah namun niat mereka tidak terlaksana karena kodifikasi Alquran lebih diprioritaskan saat itu. Niat mereka ini baru bisa direalisasikan oleh salah satu khalifah dari Bani Umayyah yang terkenal peduli terhadap kemajuan peradaban agama: Khalifah 'Umar b. 'Abd al-'Aziz.

Kodifikasi hadis yang dimulai pada penghujung abad pertama ini terus dilakukan dari tahun ke tahun, hingga pada abad ke-3 kodifikasi hadis terutama kitab-kitab hadis primer sudah terkumpul secara sempurna dan mulai dilakukan penggandaan naskah. Konsentrasi ahli hadis pada saat itu adalah kepada sanad. Tidak ada satu kitab hadis pun yang tidak menyebutkan sanad secara lengkap. Prinsip kesahihan hadis tergantung pada kesahihan sanad, jika sanadnya sahih maka secara umum hadis itu pasti sahih. Betapapun ketatnya standar yang mereka terapkan, tetapi mereka tidak bisa menghalau arus israìilyat yang lolos dan mewarnai hampir semua kitab hadis.

Hal yang juga penting untuk dicatat, bahwa salah satu kekurangan ahli hadis klasik adalah minimnya perhatian terhadap kritik matan, karena fokus mereka terpaku pada penelitian sanad sehingga tidak banyak diskusi tentang matan hadis. Pertanyaan-pertanyaan seputar matan hadis nyaris tidak pernah muncul ke permukaan, seperti bagaimana jika sebuah matan hadis bertentangan dengan fakta sejarah yang diketahui secara umum atau bertentangan dengan prinsip dasar Alquran atau adanya matan hadis yang mengandung ancaman hukuman berat atas pelanggaran sepele. ${ }^{15}$

Amin menyesalkan keterlambatan kodifikasi sunah yang menyebabkan ribuan hadis hilang bersamaan meninggalnya ratusan sahabat. Padahal jika diasumsikan bahwa setiap satu sahabat memiliki

\footnotetext{
14 Amin, Fajr al-Isläm, 208-210.

15 Amin, Yawm al-Islàm, 14-15.
} 
minimal satu hadis saja, sementara jumlah sahabat wafat-baik karena perang atau lainnya - adalah 114000 jiwa, maka dengan angka itulah jumlah hadis. Jika separuh saja dari mereka memiliki 10 hadis atau lebih maka betapa banyaknya hadis yang dapat dicatat. Namun harapan itu memang sulit direalisasikan mengingat sahabat kala itu, selain gugur, sudah tersebar di berbagai penjuru dunia dan tidak mungkin menghadirkan semuanya di Madinah untuk diambil hadisnya satu per satu.

Pada abad pertama, secara historis tidak ditemukan satu kitab pun yang berisi kumpulan hadis yang berhasil dikumpulkan oleh Muhammad b. Shihāb al-Zuhrì maupun Abū Bakr b. Hazm. Justru kitab hadis pertama yang berhasil ditulis adalah kitab al-Muwatta' karya Imām Mālik, murid al-Zuhrì pada awal abad kedua. Imām Mālik menulis al-Munatța' atas saran dari khalifah Abū Ja'far al-Manșūr yang meneruskan pemikiran 'Umar b. 'Abd al-'Aziz. Khalifah Harūn alRashid juga pernah meminta Mālik untuk menyetujui niatnya menggantung al-al-Muwatta' di dinding Ka'bah supaya menjadi pegangan amalan bagi semua umat Islam, namun Imām Mălik menolak karena hal itu menurut Mālik akan mencederai kebebasan umat Islam dalam bermazhab. ${ }^{16}$

\section{Permulaan Pemalsuan Hadis}

Aḥmad Amin menganggap bahwa tidak adanya proses pengumpulan hadis pada masa Rasulullah atau pada masa-masa pertama kekhalifahan adalah penyebab banyaknya aksi pemalsuan hadis. Bahkan menurut Amin, pemalsuan hadis eksis sejak masa Rasulullah, adanya hadis ancaman neraka bagi pemalsu hadis, ${ }^{17}$

\footnotetext{
16 Amin, Fajr al- Islam, 221-222.

17 Terdapat beberapa redaksi tentang hadis ancaman neraka bagi pemalsu hadis ini. Menurut Ibn Salah, bahwa hadis ini berstatus Mutawatir karena diriwayatkan oleh puluhan sahabat yang jumlahnya mencapai 62 sahabat. Ini adalah satu-satunya hadis mutawatir yang diriwayatkan oleh 10 sahabat yang dijamin surga. Lihat Ibn Majah, Sunan Ibn Mäjah, vol. 1 (Kairo: 'Isā al-Bāb al-Halabi, t.th.), 13. Variasi redaksi hadis ini antara lain:

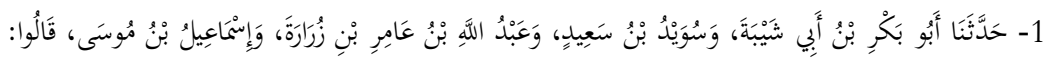

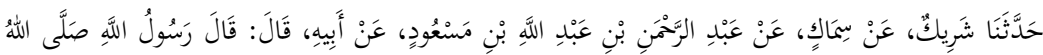

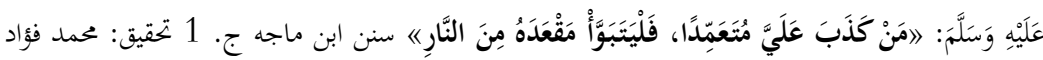

$$
\begin{aligned}
& \text { عبد الباقي (القاهرة : عيسى البابي الحلبي، بدون السنة) ص صدئ } 13
\end{aligned}
$$


menjadi indikasi kuat akan adanya upaya pemalsuan hadis pada masa Nabi, dan setelah Nabi wafat, upaya pemalsuan itu menjadi lebih banyak dijumpai. ${ }^{18}$

Pendapat ini menuai banyak kritikan dari ulama. Salah satunya adalah counter yang dikemukakan oleh Muștafa al-Siba $\overline{\bar{c}} \bar{i}$ bahwa artikulasi ini justru melupakan fakta sejarah dan sedikitpun tidak menoleh kepada sabāb al-wurüd hadis ancaman pemalsuan ini. Tidak satu pun riwayat yang menjadi sabāb al-wurüd hadis ini menyebutkan adanya peristiwa pemalsuan perkataan Nabi yang dilakukan oleh sahabat, sebab sahabat adalah-mengikuti klaim umum-telah dikenal sebagai orang yang 'adil'. ${ }^{19}$ Mengenai banyaknya hadis ancaman bagi pendusta ini menurut al-Siba $\bar{i}$ i harus dipahami bahwa Nabi mengatakan demikian karena beliau dibukakan ilmu Allah sehingga mampu meramalkan keadaan umat Islam di masa mendatang. Rasulullah telah memprediksi umatnya akan melakukan

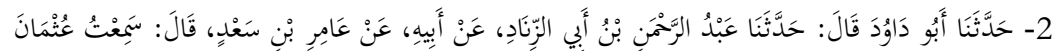

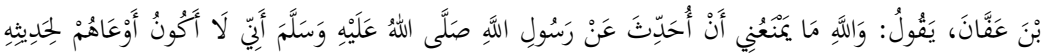

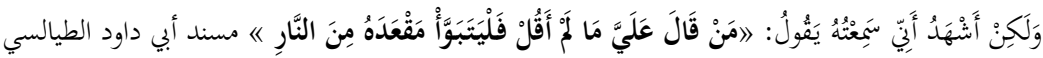

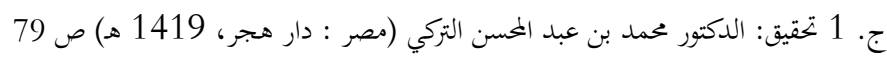

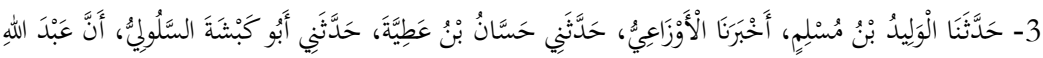

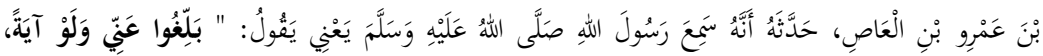

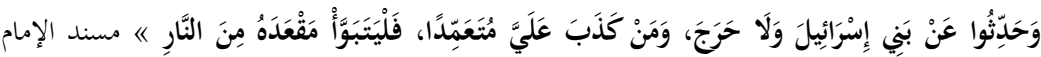

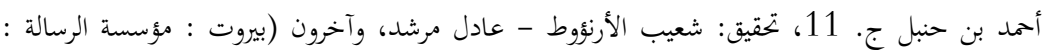

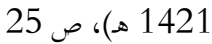

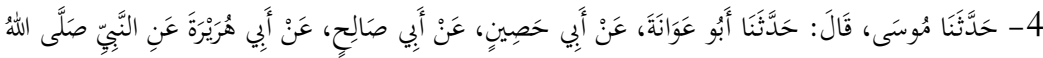

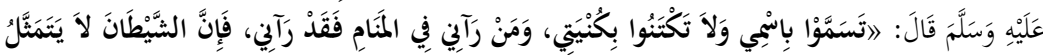

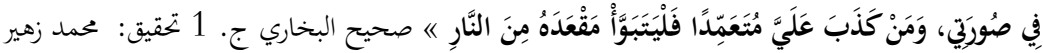

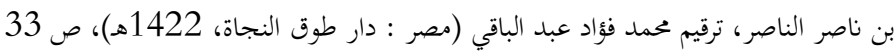

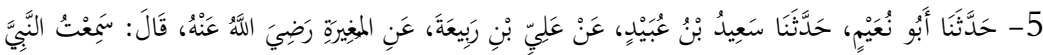

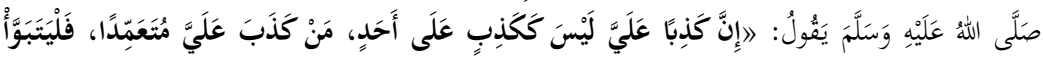

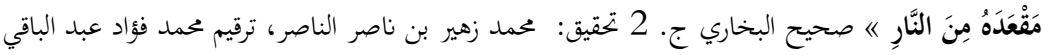

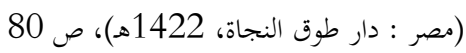

18 Amin, Fajr al-Islam, 211.

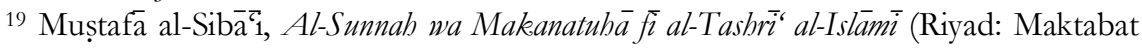
al-Warraq, 1998), 269. 
ekspansi ke beberapa belahan dunia dan menyebabkan bertambahnya pemeluk Islam dari berbagai kebudayaan. Ini akan berdampak terhadap penjagaan sunah itu sendiri karena masalah sosial kian kompleks, manusia menjadi terkotak-kotak, kehidupan dalam suasana politik tidak bisa dihindari dan masing-masing golongan saling berebut kepentingan. Keadaan inilah yang sudah dibaca jauh hari oleh Rasulullah. Dengan demikian, menurut al-Siba $\bar{i} \bar{i}$, hadis ancaman bagi pendusta itu sama sekali tidak mengindikasikan ada atau banyak pendusta di masa Rasulullah. ${ }^{20}$ Dengan logika yang sederhana saja, Rasulullah adalah sosok yang sangat dicintai, diagungkan, disegani, oleh para sahabat. Mereka rela berkorban bertaruh nyawa dan harta demi Nabi. Sahabat adalah golongan yang melindungi Rasulullah dengan sepenuh hati, tidak hanya melindungi dari serangan kaum kafir, mereka juga melindungi perasaan Nabi. ${ }^{21}$ Menjaga sunah Nabi merupakan manifestasi kecintaan kepada beliau. Pandangan Ahmad Amin tentang kemungkinan perubahan sunah oleh sahabat dapat diletakkan dalam konteks orang-orang yang menghendaki kehancuran agama, maka sahabat pendusta itu pasti sudah bukan lagi sahabat, karena sahabat Nabi tidak pernah berdusta, ${ }^{22}$ golongan ini lebih direpresentasikan oleh golongan munafik yang pada saat itu memang tidak sedikit.

Dalam bukunya, Ahmad Amin menganalisa fenomena pemalsuan hadis yang terjadi di kalangan sahabat adalah disebabkan oleh lima faktor berikut:

1. Pertikaian politik antara 'Ali dan Abū Bakr, 'Ali dan $\mathrm{Mu}^{\text {'áwiyah, }}$ 'Abdullāh b. Zubayr dan 'Abd al-Mālik, kemudian antara khalifah-khlaifah bani Umayyah dan Abbasiyah.

2. Perbedaan mazhab fikih dan kalam.

3. Ketundukan orang alim kepada khalifah atau pejabat tinggi negara untuk mendapatkan kedekatan seperti yang dilakukan oleh Ghiyāth b. Ibrāim terhadap khalifah al-Mahdi, namun sayang usahanya tidak berhasil karena khalifah al-Mahdi cukup alim dengan hadis Nabi.

\footnotetext{
20 Ibid., 267.

${ }^{21}$ Lihat Muhammad 'Ajjāj al-Khațīb, Al-Sunnah Qabl al-Tadwīn (Beirut: Dār al-Fikr, 1980), 190-191.

22 Ibn Kathir berkata: Sahabat semuanya adil menurut Ahl al-Sunnah wal Jama'ah.

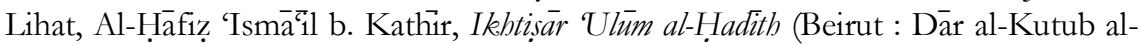
'Ilmiyah, t.th.), 182.
} 
4. Adanya upaya dari para ulama untuk membumikan ibadahibadah atau amalan-amalan tambahan seputar fada'il dan targhīib wa tarbib, dan tidak ada kaitannya dengan hukum halal haram. Hal ini menggelitik mereka untuk memalsukan hadis dengan alih-alih tujuan kebaikan. Salah satu contoh yang dilakukan Nūh b. Abi Maryam bahwa ia telah mengarang sejumlah hadis mengenai keutamaan surat Alquran, misalnya barang siapa yang membaca surat ' $x$ ' sebanyak ' $y$ ' kali maka ia akan mendapatkan pahala ' $z$ '. Hadis karangan Nūh ini seringkali ia sandarkan kepada para tokoh Alquran seperti 'Ikrimah dari Ibn 'Abbās, kadang juga ia sandarkan kepada Ubayy b. Ka ${ }^{\circ} \mathrm{b}$.

5. Adanya opini masyarakat Muslim kala itu bahwa selain hadis tidak akan digubris atau didengar. Ilmu yang sebenarnya, terutama yang berkaitan dengan hukum halal haram, adalah yang disandarkan kepada Alquran dan hadis. Jika tidak ada kaitan dengan keduanya, maka ia sama sekali tidak ada nilainya. Dari sini, timbullah keberanian dari beberapa intelektual Muslim yang ingin menyampaikan hikmah atau ilmu pengetahuan yang berasal dari Tradisi Bani Israel, India, Yunani atau Persia maka tidak ada jalan lain kecuali dengan 'menjadikannya' sebuah hadis terlebih dahulu supaya bisa diterima oleh masyarakat Muslim. Ini dapat dibuktikan dengan adanya beberapa riwayat hadis yang isrä'iliyat yang diambil dari Taurat dan Injil, hadis yang memuat hikmah India, Persia, atau filsafat Yunani kuno. ${ }^{23}$

Analisa tentang sebab-sebab terjadinya pemalsuan hadis ini, menurut hemat penulis sama sekali tidak ada hubungannya dengan keadaan sosio-kultural masa Nabi. Faktor pemalsuan hadis menurut Amin tidak dapat menguatkan pendapatnya mengenai adanya pemalsuan hadis pada masa Rasulullah. Kalaupun bisa dibenarkan, maka analisa faktor kemunculan ini hanya bisa ditarik ke masa-masa setelah Rasulullah wafat, yakni masa sahabat dan tabiin.

\section{Keadilan Sahabat}

Aḥmad Amin menyayangkan mengapa para kritikus hadis sepanjang zaman selalu menganggap semua sahabat adil. Dari sekian banyak peneliti tidak ada yang berani mengkritik sahabat apalagi

23 Amin, Fajr al-Isläm, 214-215. 
memiliki praduga bahwa salah satu mereka pernah berdusta, padahal nyata di antara mereka sering terjadi jarh, yaitu saling mencela, saling tuduh berdusta, dan saling menjatuhkan, terutama ketika mereka terlibat dalam berbagai kasus politik. Amin mengutip pernyataan alGhazāili: keadaan 'adālah mereka adalah terbatas pada masa-masa awal mereka dan berakhir ketika sudah terjadi pertikaian politik dan perang saudara antar mereka. Perubahan iklim yang terjadi dalam kehidupan sahabat mendorong untuk meneliti lebih dalam tentang keadaan mereka.

Di sisi lain, Amin berpendapat bahwa sebagian sahabat meragukan kejujuran sahabat lainnya, bahkan sampai menolak hadis yang ia riwayatkan. Kasus seperti ini banyak dijumpai dalam tradisi periwayatan pada masa sahabat, misalnya kritik 'A'ishah dan Ibn 'Abbās terhadap Abū Hurayrah, dan penolakan 'Umar terhadap riwayat Fạtimah b. Qays. ${ }^{24}$

Muștafa al-Siba $\bar{C}^{\bar{C}}$ memberikan tanggapan atas diskusi ini, ia berpandangan adanya saling kritik antar sahabat tidak berarti sebagian mereka tidak adil. Adapun jika ada kecenderungan saling tidak percaya atau saling meragukan kejujuran yang lainnya, sama sekali tidak pernah dijumpai kecuali pada masa pecahnya fitnah, lebih tepatnya sikap suka melempar vonis dusta dan caci mencaci di kalangan sahabat hanya muncul dari golongan Shi'ah Rāfiḍah ${ }^{25}$ dan Khawarij.

Dalam suatu kejadian Ibn 'Abbās menegkritik Abū Hurayrah mengenai hadis tentang kewajiban wudu setelah membawa jenazah ${ }^{26}$ adalah disebabkan adanya pertentangan dengan dalil-dalil lain sehingga Ibn 'Abbās menolak hadis itu. Adapun kritik 'A' 'ishah mengenai hadis tentang perintah mencuci tangan ketika bangun tidur $^{27}$ dan kemudian 'A' 'ishah memberikan pertanyaan kritis 'bagaimana jika aku gunakan gayung?', versi yang benar adalah bahwa

24 Ibid., 216-217.

25 Al-Sibā̄í Al, Aunnah wa Makanatubā, 292.

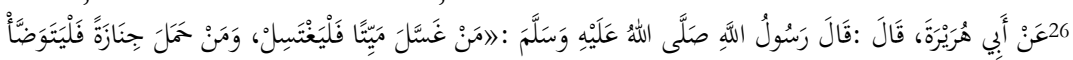

27 Bandingkan dengan riwayat ini :

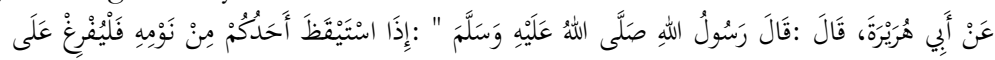

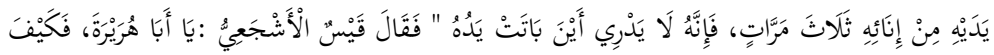

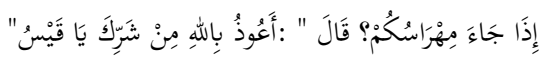

Lihat Ahmad b. Ḥanbal al-Shaybāni, Al-Musnad, vol. 14 (Beirut: Mu'assasat alRisālah, 2001), 524. 
yang melempar pertanyaan kritis tersebut bukan 'A' ishah melainkan Qain al-Ashjāi dari kalangan tabiin sebagaimana diungkap oleh Ibn 'Amir Hajj. ${ }^{28}$ Sedangkan hadis yang dibawakan oleh Ahmad Amin tidak ditemui di semua kitab hadis baik primer maupun sekunder. Menurut pengakuannya, hadis yang menyebutkan bahwa penanya kritis itu adalah ' $\overline{\mathrm{A}}$ 'ishah ada di dalam kitab Sharb Musallam al-Thubüt. ${ }^{29}$ Demikian bahwa dalil yang digunakan oleh Ahmad Amin menurut alSibāi tidak bisa dijadikan hujah karena hadis yang ia gunakan tidak ditemukan dalam referensi kitab hadis. ${ }^{30}$

Adapun penolakan 'Umar terhadap riwayat Fạtimah b Qays bukan berarti 'Umar menganggap Fatimah seorang pembohong. 'Umar menolak hadis Fatimah b. Qays karena ia bertentangan dengan dalil-dalil yang lebih kuat dari Alquran maupun sunah. ${ }^{31}$ Riwayat yang berisi celaan "Umar, "kita tidak tahu apakah dia jujur atau pembohong" tidak ditemui di dalam sahịhayn, justru di dalam șahihayn menggunakan pernyataan "kita tidak tahu apakah ia hafal atau lupa". Dengan demikian, maka redaksi yang dikemukakan oleh Amin adalah shädh (lemah), sementara redaksi yang terjaga adalah riwayat Muslim, Abū Dāwūd dan al-Tirmidhi. ${ }^{32}$

\section{Abū Hurayrah}

Abu Hurayrah adalah perawi hadis dari kalangan sahabat yang paling banyak meriwayatkan hadis. Jumlah hadis yang diriwayatkan tercatat sebanyak 5374, sementara 'Abdullāh b. 'Umar menempati posisi dibawahnya dengan periwayatan sebanyak 2630, kemudian Anas b. Mālik sebanyak 2286, lalu ' $\bar{A}$ 'ishah sebanyak 2210, kemudian 'Abdullāh b. 'Abbās sebanyak 1660, Jābir b. 'Abdillāh 1540, Abū Sa ̄ìd al-Khuḍīi sebanyak 1170, lalu 'Abdullāh b. Mas'ūd sebanyak 484 hadis, 'Abdullāh b. Amr b. al-'Aṣ sebanyak 700 dan 'Ali b. Abi Ṭălib sebanyak 537 hadis. Ini adalah daftar 10 perawi terbanyak meriwayatkan hadis.

\footnotetext{
${ }^{28}$ Lihat Muhammad b. Amir Hajj, Al-Taqrì wa al-Taḅbìr (Beirut: Dār al-Kutub al'Ilmiyah, 1983), 56.

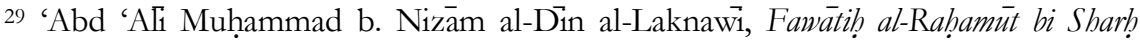
Musallam al-Thubüt, vol. 2 (Beirut: Dār al-Kutub al-'Tlmiyah, 2002), 177-178.

30 Al-Sibāi, Al-Sunnah wa Makanatuhä, 333-335.

${ }^{31}$ Ibid., 295.

32 Ibid., 294.
} 
Kenyataan Abū Hurayrah sebagai perawi hadis terbanyak merupakan hal yang susah diterima oleh akal Ahmmad Amin. Melihat masa interval bersama Rasulullah yang begitu singkat, yakni hanya sekitar 3 tahun. Sementara 'A' ishah-Istri yang selalu mendampingi selama masa beliau di Madinah hingga wafat-terhitung secara kuantitas berada jauh di bawah Abū Hurayrah. Abū Hurayrah meninggal tahun $57 \mathrm{H}$ dan 'A'ishah tahun $58 \mathrm{H}$. Artinya mereka berdua sama-sama berumur panjang dan kesempatan untuk menggali hadis dari sahabat-sahabat lain serta masa untuk meriwayatkannya sama-sama panjang. Dengan kesempatan yang sama ini ditambah keunggulan 'A' 'ishah dalam interval mendampingi Rasulullah setiap hari dan mengetahui keadaan 'privat' Nabi-yang tidak mungkin diketahui khalayak umum, Aḥmad Amin tidak bisa menerima jika Abū Hurayrah menjadi perawi terbanyak, sebaliknya ini menjadi sasaran empuk bagi para pemalsu hadis untuk memalsukan hadis dan kesempatan bagi mereka untuk menyandarkan hadis-hadis palsu kepada Abū Hurayrah sebanyak-banyaknya. ${ }^{33}$

Ahmad Amin juga mengkritik Abū Hurayrah bahwa ia sering meriwayatkan hadis yang tidak didapat secara langsung dari Rasulullah, melainkan dari sahabat lain. Amin mencontohkan hadis berikut: ${ }^{34}$

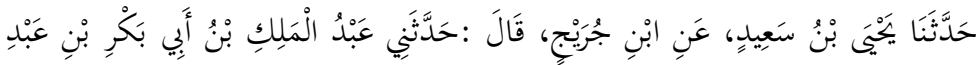

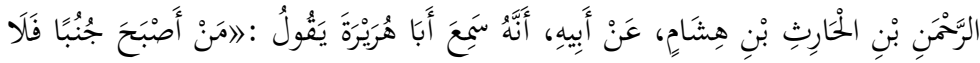

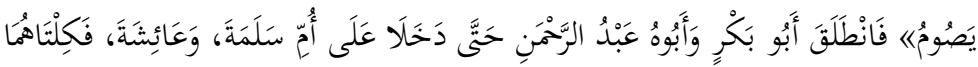

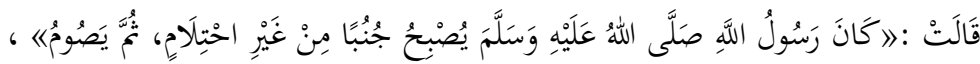

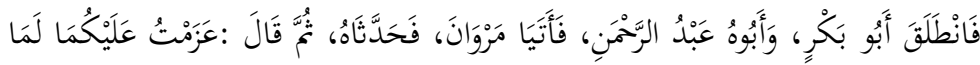

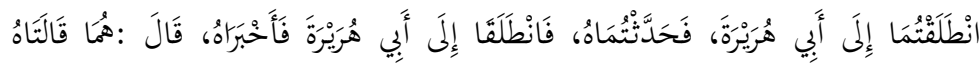

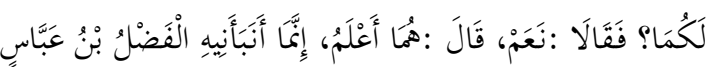

"Dari Abū Bakr b. 'Abd al-Raḥmān bahwa ia mendengar Abū Hurayrah berkata : "barangsiapa yang bangun subuh dalam keadaan junub maka tidak boleh berpuasa". Lalu Abū Bakr dan ayahnya, "Abd al-Raḥmān mendatangi Umm Salamah dan 'A'ishah. Kedua Umm al-Mu'minin itu memberikan kesaksian

\footnotetext{
33 Amin, Fajr al-Islam, 219-220.

34 Al-Shaybāni, Al-Musnad, 268.
} 
"Rasulullah SAW (biasanya) bangun subuh dalam keadaan junub (bukan dari mimpi, tetapi dari jimak) kemudian beliau berpuasa". Abū Bakr dan ayahnya lalu mendatangi Marwān dan menceritakannya dan Marwān pun menyarankan untuk menceritakan hal itu juga kepada Abū Hurayrah. Lantas mereka berdua pun menceritakannya kepada Abū Hurayrah dan Abū Hurayrah pun bertanya: benarkah kedua Umm al-Mu'minin itu berkata demikian? Mereka berdua menjawab: benar. Mereka berdua lebih tahu, saya hanya menyampaikan apa yang saya dengar dari al-Fạ̣l b. 'Abbās, terang Abū Hurayrah."

Apa yang dipermasalahkan oleh Aḥmad Amin tidak menjadi masalah bagi ulama hadis walaupun Abü Hurayrah mengambil hadis dari sahabat lain. Fakta ini juga banyak ditemukan pada kasus sahabatsahabat junior (sighār) seperti Anas b. Mālik, Ibn 'Abbās dan Ibn 'Umar atau mereka yang masuk Islam belakangan seperti al-Barrā' b. 'Azíb dan Abū Hurayrah. Kenyataan ini diakui sendiri oleh mereka, kasus seperti ini sering terjadi karena sahabat Nabi berjumlah sekian ratus bahkan ribuan dan mustahil semua sahabat itu bisa selalu mendampingi Rasulullah atau menghadiri majlis setiap hari. Mayoritas sahabat mempunyai kesibukan di luar urusan agama Islam.

Abū Hurayrah adalah satu dari sekian banyak sahabat yang memeluk Islam belakangan sehingga untuk menggali apa yang tertinggal, ia harus mendapatkannya dari sahabat lain yang mendengar langsung dari Rasulullah. Bentuk periwayatan yang di dalam sanadnya menggugurkan satu atau dua sahabat sebelum Rasulullah dinamakan hadis mursal. Namun jika yang menggugurkan itu adalah sahabat juga, maka dinamakan mursal sababī. Terjadinya mursal sạ̣abi disebabkan beberapa faktor di atas. Anas berkata: "Tidak semua yang aku riwayatkan kepada kalian adalah aku dengar (langsung) dari Rasulullah, tetapi kami sahabat Nabi tidak pernah saling berbohong satu sama lain". Al-Barrā' juga menyatakan gagasan pararel: "Tidak semua hadis yang aku dapat aku dengar langsung dari Rasulullah, sebagian hadis aku dengar dari beberapa sahabat dari Rasulullah, itu karena kami disibukkan oleh gembalaan onta". Hukum mursal sababi adalah sahih dan hadisnya bisa dijadikan hujah menurut mayoritas ulama. Mengenai kehujahan hadis mursal, al-Nawawi berpendapat bahwa mursal sạ̣abi, seperti periwayatannya tentang sesuatu yang dilakukan oleh Rasulullah atau berbentuk periwayatan lainnya, adalah 
disebabkan oleh tidak hadirnya perawi pada saat Rasulullah bersabda atau melakukan sesuatu, baik karena umurnya terlalu muda kala itu atau karena baru memeluk Islam, maka pendapat yang sahih adalah pendapat mayoritas ulama yang mengatakan bahwa hadis Mursal yang demikian itu bisa menjadi hujah. ${ }^{35}$

Berkenaan dengan hadis Abū Hurayrah di atas, al-Baghawi mengemukakan pendapat lain yang mengatakan bahwa hadis yang disampaikan oleh Abū Hurayrah tersebut adalah berdasar hukum lama pada awal-awal Islam di mana pada saat itu haram melakukan jimak pada malam-malam puasa. Ketika iman kaum Muslim semakin kuat, maka Allah memperbolehkan jimak pada malam puasa sebelum fajar terbit. Ketika fajar terbit, puasa boleh dilakukan walaupun belum melakukan mandi janabah. Fatwa Abū Hurayrah ini adalah berdasarkan hukum lama yang ia dapatkan dari al-Fạ̣l b. 'Abbās dan beliau tidak tahu kalau itu sudah di nasakh (diganti atau dihapus). Ketika mendengar apa yang diceritakan oleh 'A'ishah dan Umm Salamah, maka Abū Hurayrah meninggalkan fatwanya itu.

Ada lagi pendapat ketiga, bahwa hadis Abù Hurayrah diatas adalah khusus bagi orang yang sedang melakukan jimak di waktu yang mendekati fajar, lalu ketika datang fajar, ia masih dalam keadaan berjimak, maka ia tidak boleh melakukan puasa hari itu. ${ }^{36}$

\section{Konsep Jarh Ta'dil dan Kritik Hadis}

Al-jarh wa al-ta'dīl yang dilakukan oleh para ahli hadis menurut Amin sering dipengaruhi oleh faktor eksternal seperti karena adanya perbedaan atau fanatisme mazhab. Ini terbukti dari al-jarḅ wa al-ta'dīl antara Ahl al-Sunnah dan Syiah. Kaum Ahl al-Sunnah menolak semua riwayat 'A $\overline{l i}$ yang diriwayatkan dari teman-teman dan pengikutnya, Ahl al-Sunnah hanya menerima hadis 'Ali dari riwayat 'Abdullāh b. Mas'ùd saja. Sikap yang sama, kaum Syiah menolak semua riwayat sahabat kecuali dari jalur Ahl al-Bayt. ${ }^{37}$

Di samping itu fokus al-jarh wa al-ta'dîl yang dilakukan oleh ulama hadis hanya terbatas pada kritik sanad (kritik eksternal), kalaupun mereka melakukan kritik matan (kritik internal), hanya terbatas

\footnotetext{
35 Al-Sibāīi, Al-Sunnah wa Makanatubā, 339.

36 Al-Husayn b. Mas'üd al-Baghawi, Sharb al-Sunnah, ed. Shu'ayb al-Arnaūt, Muhammad Zuhayr al-Shāwish, vol. 6 (Beirut: al-Maktab al-Islāmi, 1983), 281.

${ }^{37}$ Amin, Fajr al-Isläm, 217.
} 
seputar kesahihan matan itu dan meneliti apakah matan itu sahih atau maw $d \bar{u} .^{38}$ Ahli hadis belum pernah meneliti matan apakah sesuai dengan realita atau tidak. ${ }^{39}$ Sebuah contoh hadis ${ }^{40}$ yang perlu dilakukan kritik matan (internal) sebagaimana dikemukakan Amin adalah:

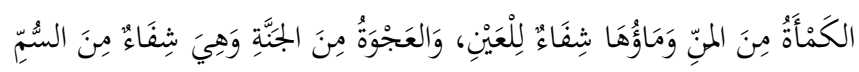

pertanyaan Amin, pernahkah ulama hadis mengkritik dan menguji hadis ini dengan melakukan praktikum mengenai kam'ah? Apakah ia memang benar mengandung zat yang bisa menyembuhkan sakit mata? Begitu juga kurma ajwah, benarkah sudah terbukti bisa menjadi penawar racun ${ }^{41}$

Terkait fanatisme golongan, Al-Siba $\overline{\bar{c}} \overline{\mathrm{i}}$ ingin meluruskan postulat yang dibangun oleh Amin, menurutnya kalangan Ahl al-Sunnah tidak pernah menolak riwayat seseorang hanya karena perbedaan mazhabnya. Para ahli hadis Ahl al-Sunnah melihat kredibilitas perawi hanya dari sisi ke-thiqqah-an yang terdiri dari ke-däbit-an dan 'adalahnya. Jika memang ada perawi Syiah yang tidak diterima oleh Ahl alSunnah, maka itu mungkin dikarenakan perawi itu dikategorikan sebagai pelaku bidah atau pengajak kepada bidah. Atau ia dikategorikan sebagai perawi yang fasik, dituduh berbohong dan sebagainya yang berkaitan dengan syarat 'adalah tadi. ${ }^{42}$

Sedangkan dalam konteks kritik konten internal, Abū Hurayrah sendiri sudah membuktikan khasiat dari kam'ah itu, begitu juga alNawawi sudah mempraktikkannya bersama ahli pengobatan pada masanya dan berhasil menyembuhkan mata buta. Ibn al-Qayyim menambahkan, dari kalangan kedokteran muslim seperti Ibn Sinā, telah membuktikan bahwa di dalam kam'ah terdapat semacam senyawa yang berkhasiat mengobati sakit mata, dan jika dipakai celak, maka membuat penglihatan semakin terang dan menghilangkan rasa pedih. Dalam Tadhkirah-nya, Daud mengatakan, air kam'ah bisa menjadikan mata lebih putih. ${ }^{43}$

\footnotetext{
${ }^{38}$ Ibid. Lihat juga Amin, Ḍụa al-Islām, vol. 1. (Kairo: Maktabat al-Usrah, 2003), 130.

${ }^{39}$ Ibid.

40 Muhammad b. 'Isāa al-Tirmidhi, Al-Sunan, ed. Muhammad Fu'ād 'Abd al-Bāāi, Aḥmad Shākir, Ibrāhìm 'Atwah, vol. 4 (Mesir: Muștafā al-Bāb al-Halabi, 1975) , 401. ${ }^{41}$ Amin, Ḍuhā al-Islām, 130-131.

42 Al-Sibāīi, Al-Sunnah wa Makanatuhä, 297.

43 Ibid., 317.
} 


\section{Riwayat bi al-Ma'nā}

Amin menyayangkan keputusan para sahabat dan tabiin yang membolehkan periwayatan bi al-ma'na dalam hadis dan menurut mereka, meriwayatkan hadis tidak harus menggunakan lafal yang digunakan Rasulullah. Kebijakan ini menurut Amin, justru mempersulit generasi berikutnya karena dihadapkan pada pilihan kata yang bermacam-macam. Misalnya dalam ungkapan ijab, ada yang menggunakan 'zamwajtukaha' ada pula 'mallaktukaha' dan ada lagi 'khudhba' bimā ma'a min al-Qur'an. Karena redaksi yang bervariasi ini, ulama nahwu tidak pernah mau mengambil contoh-contoh susunan kalimat dari matan hadis. Ibn al-Dâi berkata "adanya pembolehan riwāyah bi al-ma'nā menjadi sebab utama ulama nahwu seperti Sibawayh tidak mau menggunakan permisalan dari hadis melainkan hanya dari ayat Alquran atau syiir arab. Andai dahulu tidak ada kebijakan membolehkan riwayat bi al-ma'nā, niscaya kefasihan katakata Nabi tetap terjaga, karena Nabi adalah orang arab yang paling fasih."

Selanjutnya, Amin berpendapat ulama hadis sebagai pemantik pertikaian yang terjadi antara mereka dengan ulama fikih. Ini bermula dari celaan para ulama hadis terhadap ulama fikih yang jarang menggunakan hadis untuk menggali hukum (istinba $\bar{t}$ ) dan ulama fikih hanya mengandalkan logika atau kias. Pertikaian ini tampak terlihat antara ulama Irak (rasionalis) dan ulama Hijaz (tekstualis) pada masa Imām Mālik dan Abū Ḥanifah. Pertikaian ini berlangsung cukup lama hingga ulama hadis jarang mau meriwayatkan hadis kepada ulama hanafiyah. ${ }^{44}$

\section{Rasulullah dan Ijtihad}

Menurut Ahmad Amin, Rasulullah tidak selalu bersabda atau bertindak berdasar wahyu, adakalanya beliau berbuat sebagai manusia biasa. Sebagai manusia biasa wajar jika Rasulullah melakukan kesalahan dalam berijtihad. Salah satu contoh, Nabi mendapat teguran dari Allah melalu sebuah ayat dari surah al-Anfal karena melakukan kesalahan dalam berijtihad.

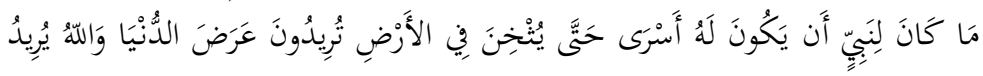

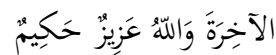

${ }^{44}$ Amin, Ḍuba al-Isläm, 133-134. 
"Tidaklah patut bagi seseorang Nabi mempunyai orang-orang tawanan kecuali untuk membunuh sebanyak-banyaknya di muka bumi. Kamu menghendaki harta benda dunia (yang tidak kekal), sedang Allah menghendaki (untuk kamu pahala) akhirat. dan (ingatlah), Allah Maha Kuasa, lagi Maha Bijaksana." ${ }^{45}$

Dalam hal ini, dapat dijumpai konsep tradisi kenabian yang dikemukakan oleh Jasser Auda, bahwa Tradisi kenabian meliputi tiga kategori: 1) Nabi sebagai pembawa risalah kenabian (wahyu), 2) Nabi sebagai hakim dan pemimpin (sinergi teks-konteks/ijtihad) dan 3) Nabi sebagai manusia biasa. ${ }^{46}$ Dengan kata lain, posisi Nabi ketika melakukan kesalahan tidak lepas dari tabiat sebagai manusia biasa.

Al-Qaraḍawi ${ }^{47}$ menawarkan konsep kesyariatan atau kewahyuan sunah yang ia bagi menjadi dua: pertama, kategori tashri (wahyu), dan kedua, kategori ghayr tashrī' (bukan wahyu). Untuk kategori yang kedua ini seorang muslim bebas memilih apakah mengikuti atau tidak. AlQaraḍ̄āi tidak mempersalahkan salah satu dari kedua aliran pada kategori kedua ini, karena masing-masing mempunyai alasannya sendiri sepanjang tidak melanggar sisi syariat. Akan tetapi al-Qaraḍ̄āi mengemukakan bahwa segala yang berkaitan dengan kebiasaan dan adat Nabi adalah sangat berkaitan dengan adat dan budaya pada masa beliau sehingga beliau dituntut untuk menghormati adat dan budaya masyarakatnya ketika itu, misalnya budaya berpakaian, cara makan dengan jari, dan sebagainya. Dalam konteks ini Nabi dikategorikan sebagai manusia biasa.

\section{Kesimpulan}

Dari uraian di atas, dapat disimpulkan bahwa kegelisahan Ahmad Amin terhadap sunnah membuktikan bahwa ia adalah seorang sejarawan kontemporer yang memandang otentitas sunah dari aspek sejarah. Beberapa pandangannya terhadap sunah cukup beragam, sebagian sejalan dengan prinsip-prinsip 'ulum al-ḥadith seperti tentang kehujahan sunah, aspek kewahyuan sunah, atau kritik sanad. Namun sebagian lain tidak sejalan dengan para ahli hadis seperti pandangan

\footnotetext{
45 Departemen Agama RI, Al-Qur'an dan Terjemahnya, 185.

46 Jasser Auda, Maqasid al-shariah as philosophy of law: a Systems Approach (London: The International Institut of Islamic Thought, 2007), 196.

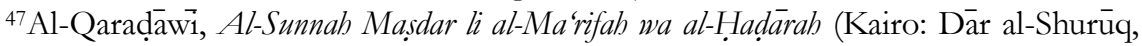
2002), 14-24.
} 
miringnya terhadap Abū Hurayrah, mengkategorikan kaum munafik dan pendusta dalam komunitas Sahabat yang berimplikasi kepada penolakan ijmak ulama bahwa semua sahabat itu adil, bahwa kritik matan belum dilakukan pada abad kedua dan ketiga, kritiknya terhadap al-jarb wa al-ta'dī Ahl al-Sunnah dan Syiah yang saling menolak periwayatan dari outsider karena perbedaan mazhab, padahal saling tolak hadis antara Ahl al-Sunnah dan Syiah bukan karena perbedaan mazhab melainkan karena perawi Syiah di mata Ahl alSunnah dikategorikan sebagai pelaku atau pendakwah bidah yang itu menjadi noda bagi ke-'adalah-an seorang perawi.

Selain itu, ketidaksetujuannya dengan riwāyah bi al-ma'nā yang menjadi sebab munculnya ambigu dalam teks hadis dan terakhir mengenai gagasannya dalam hal kewahyuan hadis Nabi, yakni tidak semua hadis Nabi adalah wahyu, karena Nabi juga seorang manusia biasa yang pastinya mustahil untuk tidak berperilaku sebagaimana manusia biasa dalam keadaan-keadaan tertentu. Pemikiran Ahmad Amin, sebagai salah satu diskurusus dalam tradisi intelektual Islam menjadi khazanah tersendiri, karena tidak hanya memberi pernyataan dogmatis, namun juga memberi alternatif penalaran kritis.

\section{Daftar Pustaka}

Amin, Aḥmad. Duhāa al-Isläm. Kairo: Maktabat al-'Usrah, 2003. - Fajr al-Islām. Beirut: Dār al-Kitāb al-'Arabi, 1969.

. Hayāti. Mesir: Kalimāt 'Arabìya, 2001.

. Yawm al-Isläm. Kairo: Hindawi li al-Ta‘'ìm wa al-Thaqāafah, 2011.

Auda, Jasser. Maqasid al-Shariah as Philosophy of Law: A Systems Approach. London: The International Institut of Islamic Thought, 2007.

Baghawi (al), al-Husayn b. Mas'ùd. Sharh al-Sunnah. Beirut: al-Maktab al-Islāmi, 1983.

Bukhārì (al), Muḥammad b. 'Ismā̄īil. Al-Jāmi' al-Șaḥị̣ al-Musnad. Mesir: Dār Tawq al-Najāh, 1422.

Departemen Agama RI. Al-Hikmah: Al-Qur'an dan Terjemahnya. Bandung: Diponegoro, 2008.

Ḥajj, Muḥammad b. Amir. Al-Taqrìr wa al-Taḥbìr. Beirut: Dār alKutub al-'Ilmiyah, 1983. 
Hurrab, M.M. Hasan. Al-Imām al-Zubrì 'Ālim al-Hijā̌ Damaskus: Dār al-Qalam, 1993.

Kathir (Ibn). Ikhtisāar 'Ulüm al-Hadìth. Beirut: Dār al-Kutub al-'Ilmiyah, t.th.

Khatib (al), Muhammad 'Ajjaj. Al-Sunnah Qabl al-Tadwīn. Beirut: Dār al-Fikr, 1980.

Laknawi (al), 'Abd al-'Ali Muḥammad b. Nizāmuddin. Fawātị̧ alRahāmūt bi Sharh Musallam al-Thubūt. Beirut: Dār al-Kutub al'Ilmiyah, 2002.

Nasā̄i (al), Aḥmad b. Shu'ayb. Al-Sunan al-Sughrā. Alepo: Maktab alMatbu'at al-Islamiyah, 1986.

Qarad̄āwi (al), Yūsuf. Al-Sunnah Mașdar li al-Ma'rifah wa al-Hadärah. Kairo: Dār al-Shurūq, 2002.

Qazwīini (al), Muḥammad b. Yazìd b. Mājah. Al-Sunan. Kairo: Dār Ihya' al-Kutub al-'Arabiyah, t.th.

Shaybāni (al), Aḥmad b. Hanbal. Al-Musnad. Beirut: Mu’assasah alRisālah, 2001.

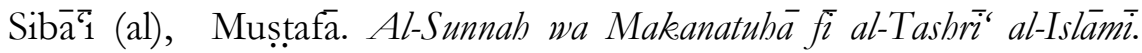
Riyad: Maktabat al-Warrāq, 1998.

Tayalisisi, Abū Dāwūd. Al-Musnad. Mesir: Dār Hajar, 1419 H.

Tabarāni (al), Sulaymān b. Aḥmad. Al-Mújam al-Kabìr. Kairo: Maktabat Ibn Taymiyah, 1994.

Tirmidhi (al), Muhammad b. 'Isā. Al-Sunan. ed. Muhammad Fu'àd 'Abd al-Bāài, Aḥmad Shākir, Ibrāhim 'Atwah. Mesir: Muṣtafā al-Bābi al-Ḥalabi, 1975. 